\title{
Dendrogeomorphology - a new tool to study drift-sand dynamics
}

\section{J. den Ouden ${ }^{\star}$, U.G.W. Sass-Klaassen \& P. Copini}

Wageningen University, Centre for Ecosystem Studies, Forest Ecology and Forest Management Group, P.0. Box 47, 6700 AA Wageningen, the Netherlands.

* Corresponding author. Email: jan.denouden@wur.nl

Manuscript received: April 2007; accepted: November 2007

\begin{abstract}
A dendrogeomorphological approach is presented, using wood characteristics of native oak (Quercus robur L.) to infer dynamics of aeolian sediment transport in drift-sand areas. Wood samples, taken from oaks in two drift-sand areas, were analysed to study changes in tree-ring pattern and wood anatomy as a consequence of burying or exposure from drift sand.

In all cases, the wood of the sampled oaks showed sudden changes in anatomy and tree-ring width due to burial by drift sand or subsequent exposure after erosion of the new soil surface. After aerial stems became covered by drift sand, the wood lost its characteristic ring-porous features, and tree rings became strongly reduced in width with less distinct ring boundaries. Buried stems that became exposed after erosion showed an abrupt increase in ring width and turned distinctly ring porous again. Roots that were exposed also adopted clear ring-porous features, increased in ring width and anatomically resembled aerial stem wood.

Using tree-ring analysis, it is possible to precisely date sand deposition and erosion events by detecting the concurrent changes in anatomy of woody structures. This study indicates the high potential of dendrogeomorphology as a tool to study drift-sand dynamics with a high temporal, i.e. annual, resolution for a period going back as long as the maximum age of the trees present (in this study at least 250 years). Since the signals of past deposition and erosion events are conserved in the wood, this is the only method that can be used to reconstruct drift-sand dynamics when the actual landforms are no longer present.
\end{abstract}

Keywords: drift sand, erosion, Quercus robur, tree-ring analysis, wood anatomy

\section{Introduction}

The Netherlands contain the largest area of active drift sands in northern Europe, but this area is rapidly declining. During the past centuries, the area of active drift sand has decreased from approximately $800 \mathrm{~km}^{2}$ in 1850 and $40 \mathrm{~km}^{2}$ in 1980 to only $15 \mathrm{~km}^{2}$ in 2000 (Bakker et al., 2003; Riksen et al., 2006; Fig. 1). Large-scale afforestations, changes in land use, and increased nitrogen deposition have all contributed to the rapid consolidation of active drift sands. Concurrently, species related to drift sands have become rare or locally extinct (Bal et al., 2001). To curb this trend, drift sand areas have been designated a protected habitat type within the European Natura 2000 network. Many efforts are now made to conserve the last remaining drift-sand areas, or restore the consolidated drift sand by removing all vegetation and topsoil, and clearing surrounding forests to increase landscape erodibility.

The future development of the current drift-sand areas or the potential of their successful restoration depend on a better understanding of those external factors that are driving the system: climate, landscape erodibility and land use (Koster, 1978; Bakker et al., 2003; Riksen et al., 2006). There are, however, no long-term data sets available on the direct relation between these factors and aeolian activity. The reconstruction of sediment transport and erosion, based on dated events in the past, allows studying dynamics of aeolian activity in retrospect, and linking it to climatic events and changes in landscape structure. 


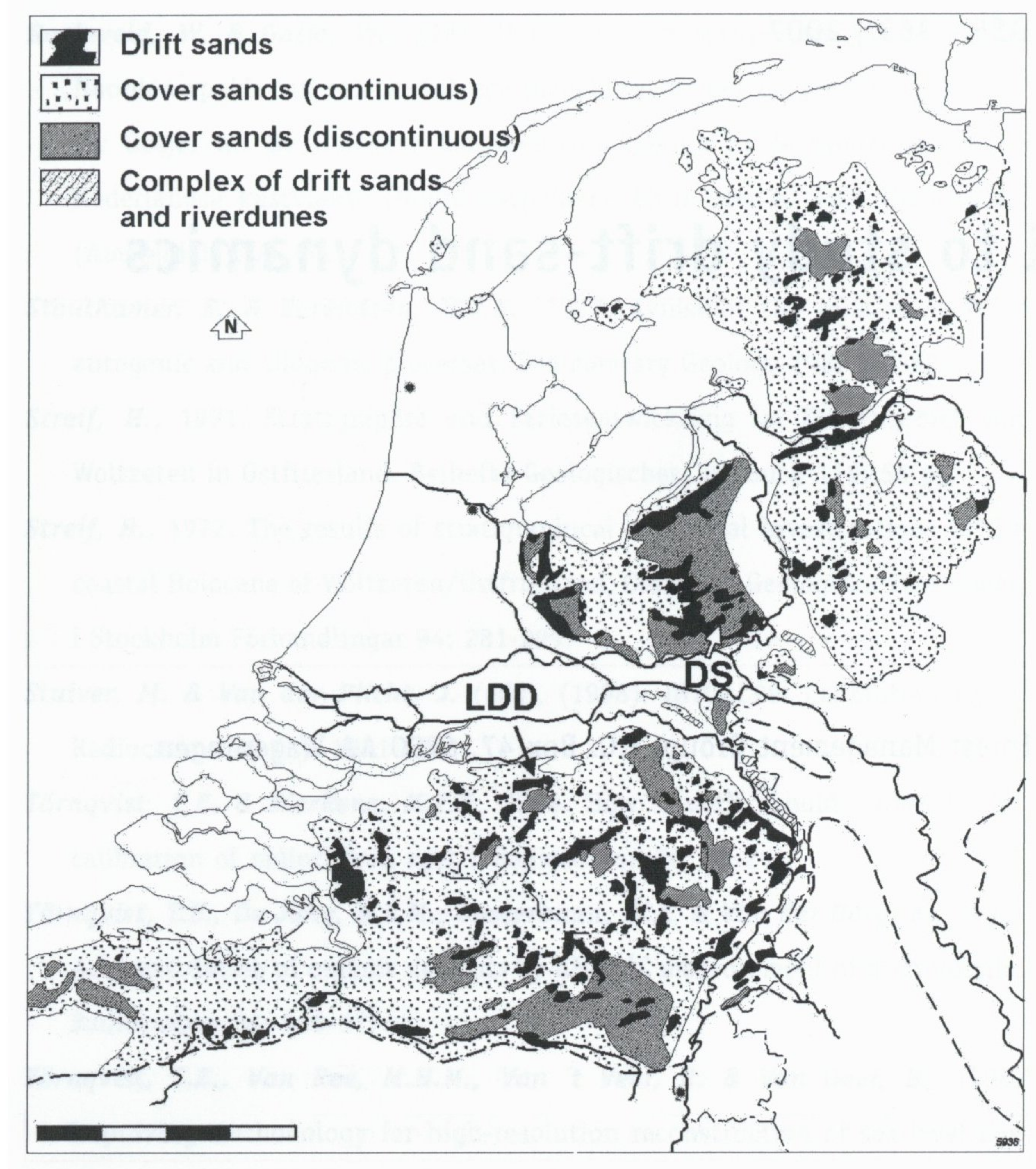

Fig. 1. The expanses of drift sand areas in the Netherlands and northern Belgium, within the matrix of cover sands from which these drift sands originated. Most drift sands are now consolidated. The locations of the research sites are indicated by DS (Deelensche Start) and LDD (Loonse en Drunense Duinen). Figure after Koster (2005).

The large Dutch drift sands originate from the medieval period (Koster, 1978). Their origin could be dated with conventional dating techniques, such as ${ }^{14} \mathrm{C}$, of the palaeosoils underneath the drift sand deposits. However, ${ }^{14} \mathrm{C}$ dating of dune formation is only possible if enough carbon has accumulated in the overblown surface. This implies that between vegetated periods, gradual build-up of the dunes cannot be followed due to the lack of suitable organic material for ${ }^{14} \mathrm{C}$ dating. Combined with the wide confidence interval, this makes ${ }^{14} \mathrm{C}$ dating not suited to answer questions related to fine scale processes within the drift-sand system that vary on a annual to decadal scale. The recently developed technique of Optically Stimulated Luminescence (OSL) dating has made it possible to study sanddeposition phases with considerably higher accuracy (Ballarini et al., 2003; Wallinga et al., 2007).

In this paper we propose a novel method for dating driftsand dynamics using the anatomical changes in the wood of trees that are (partially) covered by drift sand, or have become exposed after erosion. The detection of abrupt changes in wood anatomy in combination with dendrochronology allows dating deposition and erosion events to the exact year. This will enable us to reconstruct aeolian activity with unprecedented precision.

The application of dendrochronological techniques in geomorphology has led to the development of dendrogeomorphology (e.g. Alestalo, 1971; Gärtner et al., 2001; Bodoque et al., 2005). Especially in mountainous areas, studies on coniferous tree species like Norway spruce (Picea abies (L.) Karst.), European larch (Larix decidua P. Mill.) and Scots pine (Pinus sylvestris) have been able to exactly date and reconstruct geological events such as land slides and avalanches. This was done by using sudden changes in the wood anatomy of roots that occurred after exposure as time markers (Gärtner et al., 2001; Gärtner, 2003, 2007; Bodoque et al., 2005). Also, the covering of stems and roots by sand results in distinct changes in the wood anatomy. This enables the detection of the burial time with approximate annual precision (Cournoyer \& Filion, 1994).

Recently, the possibilities of using broadleaved species have been explored to reconstruct erosion effects on ash (Fraxinus excelsior L.) and beech (Fagus sylvatica L.). These studies were able to date the exact year of exposure (Sahling et al., 2003; Hitz et al., 2006). To our knowledge, no research has yet been conducted to test whether broadleaved species can be used to study the time of burial due to geomorphic events.

In this paper we explore the potential of dendrogeomorphology, using native oak (Quercus robur L.), to reconstruct aeolian sediment transport in drift-sand areas with high accuracy. Specific questions we address are (1) what are the effects of covering by sand and exposure on the wood anatomy of stems and roots of oaks, and (2) can we exactly date the year of burial and/or exposure?

\section{Methods}

\section{Trees in drift sand}

Trees frequently establish in drift-sand areas, mainly in local areas where vegetation cover has developed in later stages of the succession. Oak (Quercus robur, Q. petraea (Matt.) Liebl.), Scots pine (Pinus sylvestris L.) and Birch (Betula pendula Roth) are the main species occurring in Dutch drift sand (Fanta, 1982). Birch has a short life span, leaving oak and pine as the most promising species to be used for a dendrogeomorphological study. Scots pine was imported on a large scale in afforestations of drift sand during the late 19th and first half of the 20th century. Older trees are usually oaks. These may be trees that have spontaneously established from seeds, or have been planted and managed to serve as sand traps (Buis, 1985).

0aks occur as single trees or clustered in groups in driftsand areas (Fig. 2). The clusters of oak are characterised by having many stems growing closely together, and DNAanalysis has shown that such oak clusters consist of a single or a few different genotypes forming one or more clones (Copini et al., 2005). These clusters originate from oak shrubs or trees that have been partially covered by drift sand (Tesch et al., 1926; Stoutjesdijk, 1959; Copini et al., 2005). 
Fig. 2. Drift sand area in the Loonse en Drunense Duinen (LDD) with scattered oaks. What appears as oak shrubs are the crowns of partially overblown trees.

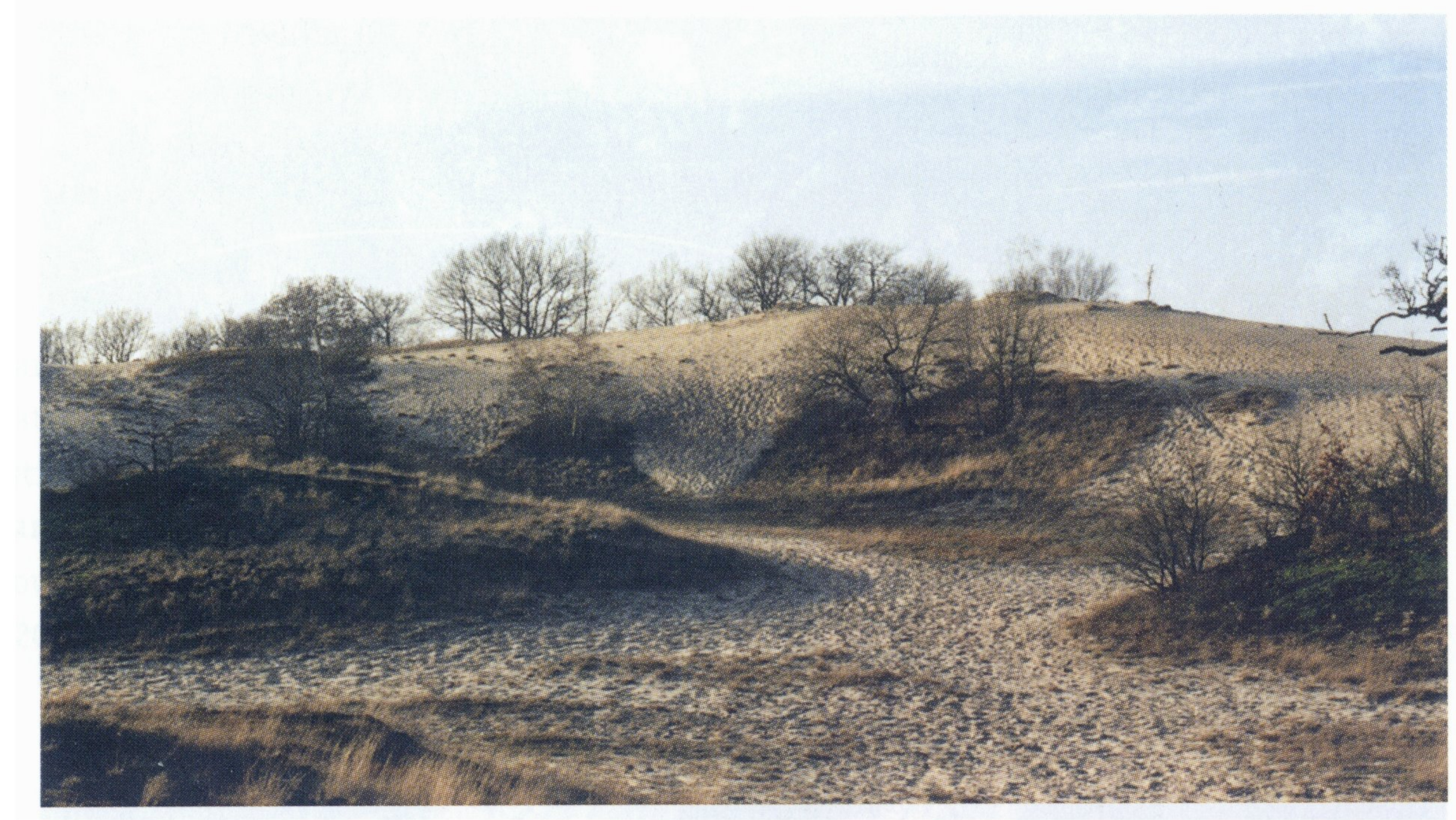

\section{Study area and sampled trees}

Two drift-sand areas were selected (Fig. 1): the Deelensche Start (DS) in the central part of the Netherlands $\left(52^{\circ} .05^{\prime} \mathrm{N}\right.$, $5^{\circ} .50^{\prime} \mathrm{E}$ ), and Loonse en Drunense Duinen (LDD) in the south $\left(51^{\circ} .40^{\prime} \mathrm{N}, 5^{\circ} .05^{\prime} \mathrm{E}\right)$. In these areas, oak trees were present as clusters that appeared as having been covered by sand, and subsequently exposed again after erosion. These trees provided an excellent opportunity to study the effect of presumed burial and exposure on the wood anatomy in both stems and roots, as they could be easily accessed for sampling.

In LDD we selected an oak cluster on an eroded nebkhar dune (Fig. 3). This cluster was $8 \mathrm{~m}$ in diameter and consisted of stems growing on a complex network of stem- and root-like structures. Distinctly thickened stem parts marked the transition between the stems and the lower network. Directly below these, remnants of adventitious roots were present, so we assumed that the area directly below the thickened parts represented a former soil surface (Fig. 3; see also Marin \& Filion, 1992; Strunk, 1997; Maun, 1998).

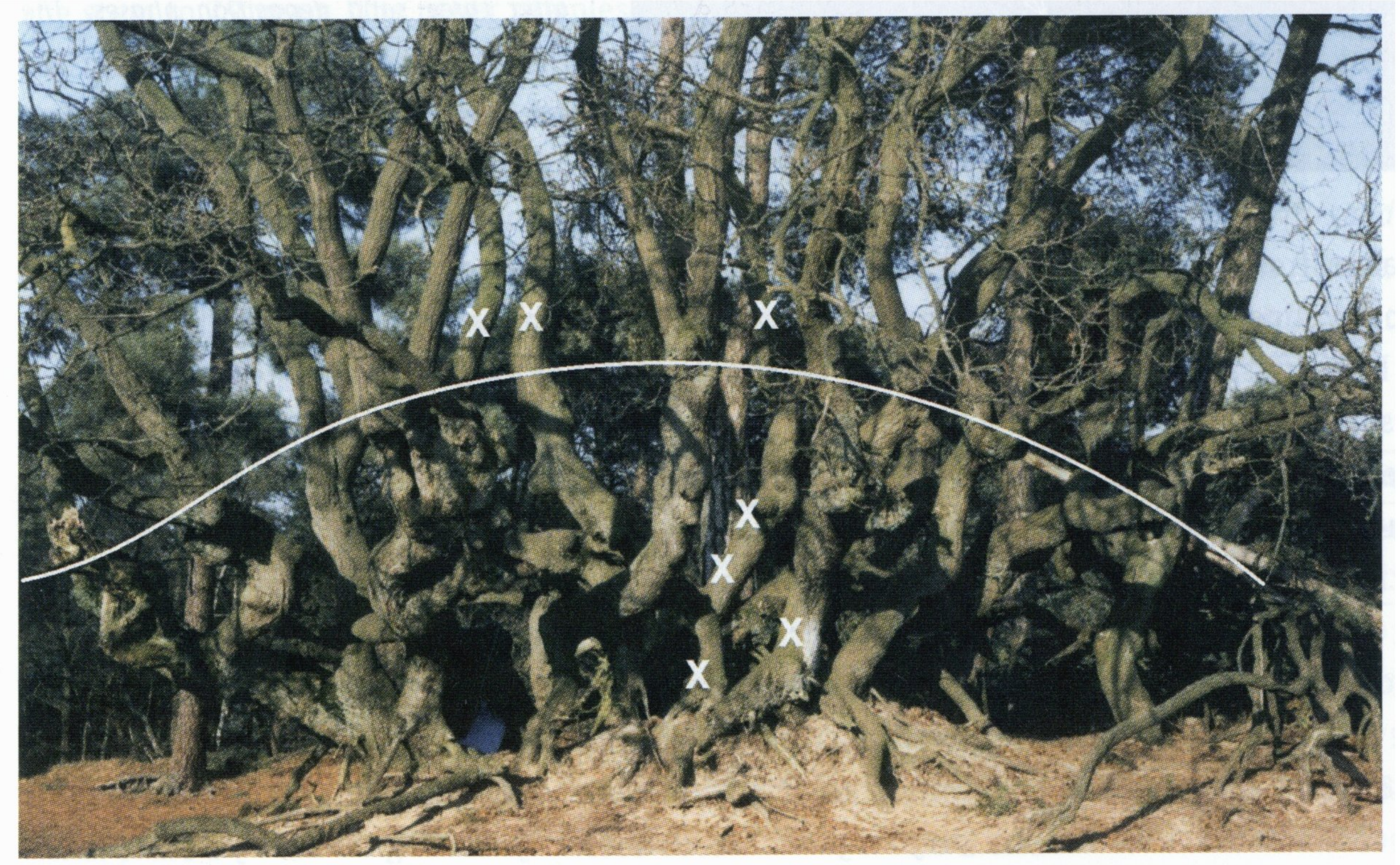

In DS, we selected oaks growing on a dune ridge (randwal). These oaks formed small clusters, consisting of several stems, and also showed a transition between aerial stems and a network of stem and root-like structures marked by a thickening of the stem, below which point adventitious roots were present at several heights. Analogous to LDD, we assumed that these trees were exposed by erosion after they had been buried by drift sand in a previous phase (Fig. 4).

\section{Sample collection and processing}

Samples were collected in the winter 2005/2006 using an increment corer (essentially a hollow drill). From the selected trees, a series of samples was taken from $0.4 \mathrm{~m}$ above the thickened stem parts (above the line in Figs 3 and 4), representing stem growth that was not influenced (unaffected) by drift-sand burial or exposure. From the oak cluster at LDD we took samples from three unaffected stems and from DS seven unaffected stems were sampled.

Fig. 3. Oak cluster in the Loonse en Drunense Duinen (LDD). The line follows the level where stems were thickened, indicating the former soil level. The four crosses below the line indicate sample locations at heights of $0.2,0.4,0.8$ and $1.2 \mathrm{~m}$. The sample taken at $0.4 \mathrm{~m}$ (cross at the right) is shown in Fig. 5. The crosses above the line indicate sample locations in stems that were not affected by driftsand burial. 

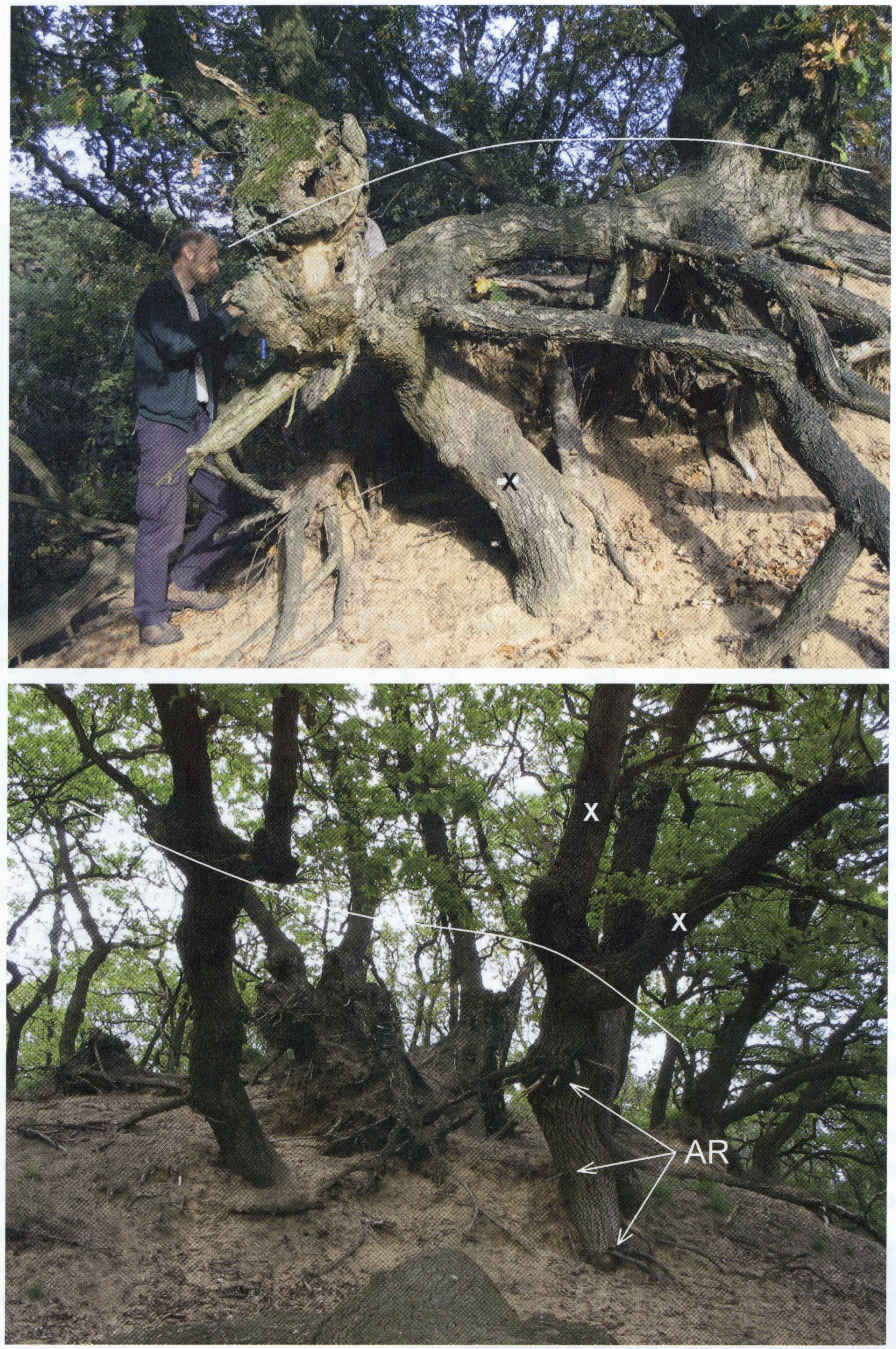

Fig. 4. Two oak clusters growing on a dune ridge in the Deelensche Start (DS). The line follows the level where stems were thickened, indicating the former soil level. Top: The cross indicates the sample location of one of the two cores drawn from the structure, and presented figures 6 and $7 B$. Bottom: The arrows indicate the zones of adventitious roots (AR) that were formed after three sand deposition phases. The crosses indicate sample locations in two out of seven sampled stems that were not affected by drift-sand burial.
The second series of samples was taken from parts of the structure below the thickened stems, (below line in Figs 3 and 4), and were assumed to be affected by drift-sand covering and subsequent exposure after the soil surface eroded. In LDD, two cores were collected from opposite directions at a stemlike structure at ca $0.4 \mathrm{~m}$ above the current soil surface (Fig. $3)$. Both cores extracted at this position contained all tree rings from pith to bark allowing us to date (changes in) the wood structure over the entire lifetime of this structure. Along another stem-like structure located in the inner part of the cluster we collected samples at $0.2,0.8$ and $1.2 \mathrm{~m}$ above the current soil surface (see Fig. 3).
At DS two cores were collected from a stem-like structure approximately $0.8 \mathrm{~m}$ below the thickened stem part at opposite sides of the structure (Fig. 4).

\section{Detecting changes in wood anatomy}

The surface of all wood samples was carefully prepared with razor blades in order to make the tree rings well visible. Visual inspection of the wood anatomy was done under a Leica stereomicroscope (magnification from 20 to 120 times). The wood anatomy of oak stems (aerial parts) is characterized by very large vessels in the early wood (produced just before the 
start of the growing season), making it distinctly ring porous. In the late wood, produced in the summer, smaller vessels are arranged in flame-like groups (fig. 7B1). In root wood (subterraneous parts), the ring-porous feature disappears (fig. 7A1). Also, the root either lacks a central pith, or the pith has a clearly different shape as compared to the stem wood (Schweingruber, 2001). However, near the root collar the difference between stem and root anatomy is often gradual. All tree rings were inspected for distinct changes in wood anatomy. The exact year in which changes in wood anatomy were detected was determined by counting back from the outermost ring, which was formed in 2005.

\section{Tree-ring analysis}

Tree-ring widths were measured to the nearest $1 / 100 \mathrm{~mm}$ using dendrochronological measuring equipment (LINTAB, TSAP; Rinn, 1996). Of the previously buried stems, only one sample per site was available that covered the entire radius of the stem, including the juvenile part in the centre. Of the remaining samples, dating was confined to the youngest, outer part of the radial as the inner part included rotten segments. The tree-ring series were visually and statistically (cross-)dated using the programs TSAP (Rinn, 1996) and COFECHA (Holmes, 1983; Grissino-Mayer, 2001). Subsequently, chronologies (= mean curves) were calculated per oak cluster from the unaffected and previously buried parts to check for differences in growth pattern and to exactly date the tree rings where changes in wood anatomy were observed.

\section{Results}

For both study sites, all samples from the upper, unaffected stem parts showed the typical anatomy of aerial stem wood with a ring-porous structure. One sample from LDD contained the central pith, which enabled exact age determination of the stem to 79 years. The other samples from LDD were broken and missed the inner rings, but due to similarity in stem morphology and tree-ring pattern these stems most likely originated at the same time, i.e. around 1927 (Table 1). Most of the seven stems at DS also lack the pith but the maximum number of tree rings counted in one stem amounts to 87 , indicating initiation of the unaffected stems around 1919 (Table 1). The average tree-ring width of the unaffected stems was $0.90 \mathrm{~mm} \pm 0.62 \mathrm{~mm}$ (mean $\pm 1 \mathrm{sd}$ ) for the three stems at LDD, and $1.36 \pm 0.72 \mathrm{~mm}$ for the seven stems at DS (Table 1). The mean tree-ring series of the oaks from LDD and DS are illustrated in Figures 5 and 6 (blue line) respectively, and show that the growth level of the oaks is relatively low with the exception of the first ca 10 years where very wide tree rings were formed. This means that the unaffected stems started to grow very fast in the beginning.

The stems below the thickened parts of the two clusters at LDD and DS differed in age. The oldest dated stem at LDD contains 150 tree rings and hence dates back to 1855 (Fig. 5). At DS the sampled stems were exactly 100 years older, dating back to 1755 (Fig. 6). Three distinct phases with clear transitions in tree-ring width and wood anatomy can be distinguished in both sites (Table 1, Figs 5 and 6). First, a (juvenile) phase is present with extremely wide tree rings during the first ca 10 years - comparable to the initial phase in the unaffected stems (blue line) - followed by the formation of somewhat smaller rings (Fig. 7). The wood that was formed during this first 50 to 60 years in both sites has a ring-porous structure and clearly resembles stem wood (Fig. 7).

The start of the second phase is marked by a transition in both tree-ring width and wood anatomy, and occurred in 1917 in LDD and in 1824 in DS. In both sites mean tree-ring width decreased considerably (below $0.3 \mathrm{~mm}$, Table 1) with the consequence that the annual variation is clearly reduced (Figs 5 and 6 , red lines). Latewood formation is strongly reduced and mean vessel area declined (Figs 5 and 6 ) which makes that the tree-ring structure ultimately became diffuse porous during this second phase (Fig. 7).

The third phase started in 1966 at LDD and in 1996 at DS. Again, a clear transition occurred with pronounced changes in tree-ring width and wood anatomy: tree-ring width abruptly increased and regained values similar to the period before the

Table 1. Average ring width from wood samples taken from oaks growing in two drift-sand areas. The oaks grew as multi-stemmed clusters, and showed distinctly thickened stems. Samples were taken from stems above, and from the structures below, these thickenings. In the lower samples, three distinct phases were present with different wood anatomy. They were identified as aerial stems that became buried and were later exposed again after erosion (aerial phase 2).

\begin{tabular}{|c|c|c|c|c|c|c|}
\hline \multirow[t]{2}{*}{ Sample location } & \multicolumn{3}{|c|}{ Loonse en Drunense Duinen } & \multicolumn{3}{|c|}{ Deelensche Start } \\
\hline & $\mathbf{N}$ & $\begin{array}{l}\text { Period represented } \\
\text { in samples }\end{array}$ & Ring width $(\mathrm{mm} \pm \mathrm{SD})$ & $\mathbf{N}$ & $\begin{array}{l}\text { Period represented } \\
\text { in samples }\end{array}$ & Ring width $(\mathrm{mm} \pm \mathrm{SD})$ \\
\hline Stems above thickening & 3 & $1927-2005$ & $0.90 \pm 0.62$ & 7 & $1919-2005$ & $1.36 \pm 0.72$ \\
\hline Structure below thickening Total & 1 & $1855-2005$ & $0.62 \pm 0.50$ & 1 & $1755-2005$ & $0.55 \pm 0.54$ \\
\hline Aerial phase 1 & & $1855-1916$ & $0.79 \pm 0.60$ & & $1755-1823$ & $1.58 \pm 0.91$ \\
\hline Buried phase & & $1917-1965$ & $0.28 \pm 0.05$ & & $1824-1995$ & $0.29 \pm 0.11$ \\
\hline Aerial phase 2 & & $1966-2005$ & $0.79 \pm 0.43$ & & $1996-2005$ & $1.16 \pm 0.57$ \\
\hline
\end{tabular}




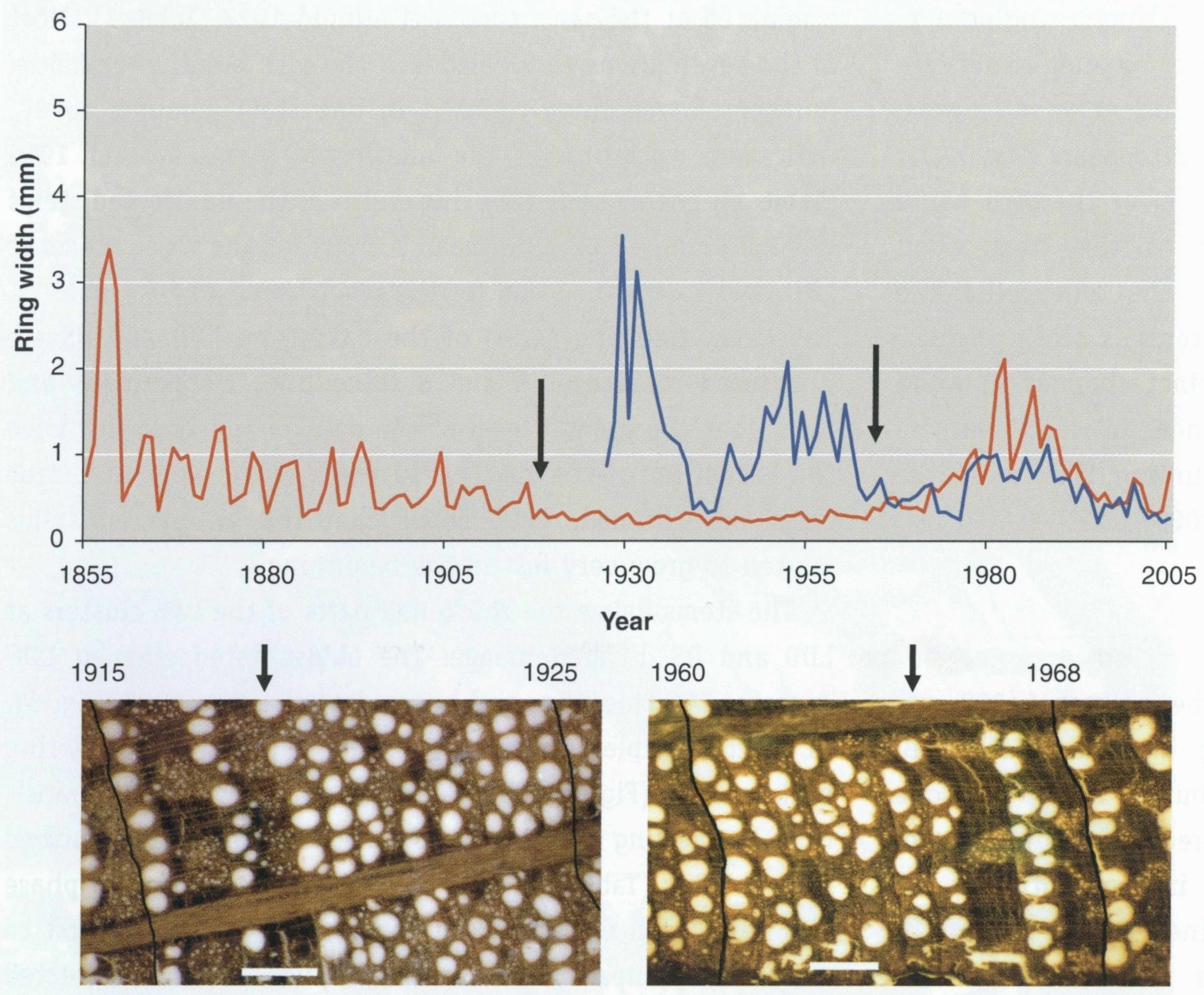

Fig. 5. Changes in ring width and anatomy in the wood of a stem-like structure of an oak (Quercus robur) in the Loonse en Drunense Duinen (LDD).

Top: Cluster chronology (1927 till 2005) of three stems sampled above the thickened stem parts (see Fig. 3), and the average ring width (1855 - 2005) from two samples drawn from a woody structure below the thickened stem parts, $0.4 \mathrm{~m}$ above the current soil surface. The arrows indicate the years in which transitions in wood anatomy occurred.

Bottom: Photographs of the transition zones where normal stem wood changed into buried stem wood and vice versa. The numbers indicate the year in which the first and last complete visible tree ring on the photograph was formed. The arrow indicates the point where the transition occurred. Growth proceeds from left to right. long-term growth depression (Table 1). The tree rings became clearly ring porous again and the average size of the earlywood vessels increased (Fig. 7).

In LDD, only single wood samples were collected at $0.2,0.8$ and $1.2 \mathrm{~m}$ above the current soil surface underneath the thickened stem parts (Fig. 5). As the inner, juvenile parts of these cores were partly broken, exact dating was impossible. However, we were able to visually discern changes in wood-

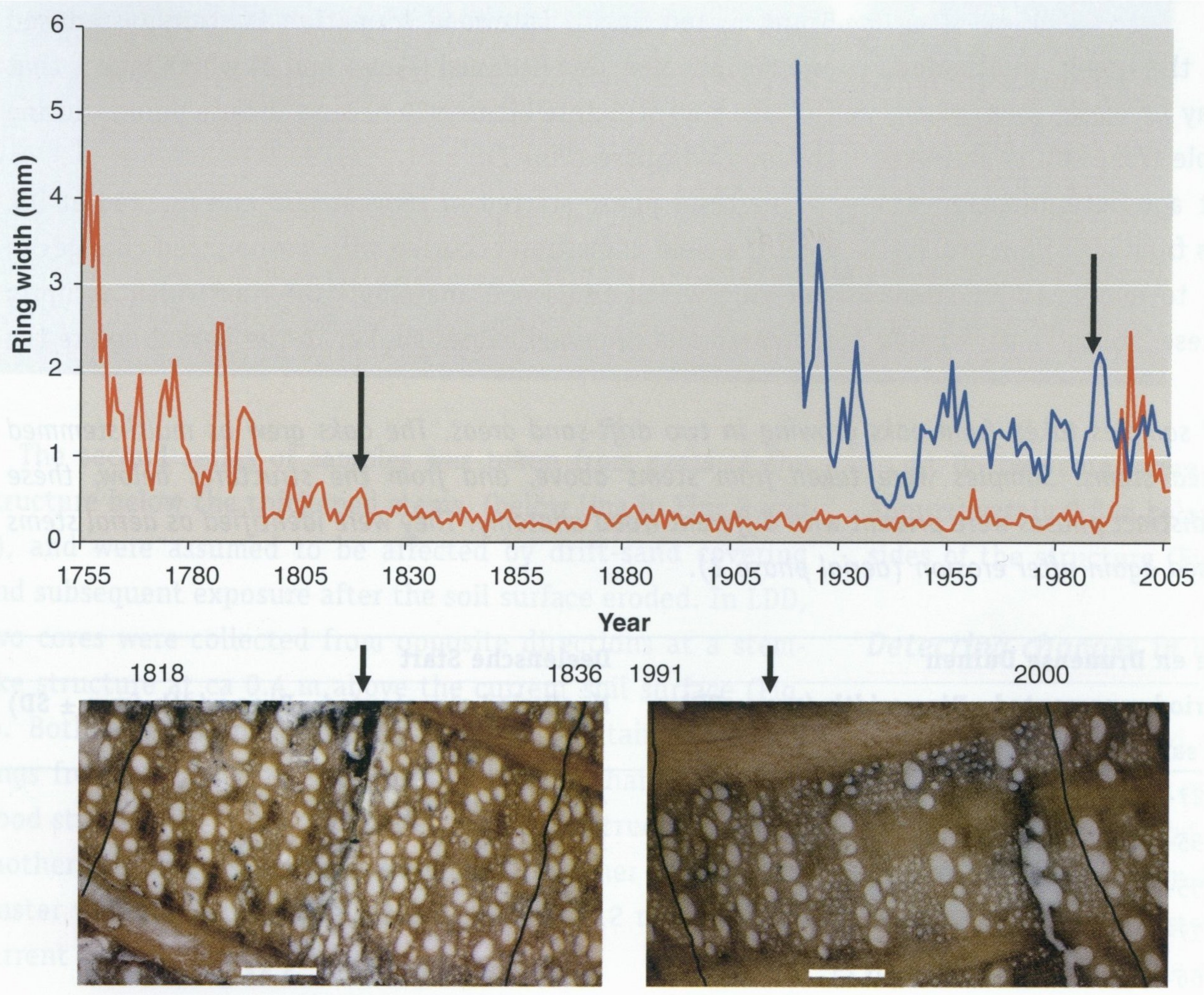

anatomical features in the juvenile part. We were able to date the year in which the second transitions took place. The innermost part of the sample taken at $0.2 \mathrm{~m}$ above the current soil surface clearly contained root wood (Fig. 7A1) whereas the two samples taken at $0.8 \mathrm{~m}$ and $1.2 \mathrm{~m}$ above the current soil surface started growing as aerial stems. All three samples also showed two distinct transitions in wood anatomy and ring width. As in the earlier described sample (Fig. 5, red line and

Fig. 6. Changes in ring width and anatomy in the wood of a stem-like structure of an oak (Quercus robur) in the Deelensche Start (DS).

Top: Cluster chronology (1919 till 2005) of seven stems sampled above the thickened stem parts (see Fig. 4), and the average ring width (1755 - 2005) from two samples drawn from a woody structure below the thickened stem parts. The arrows indicate the years in which transitions in wood anatomy occurred.

Bottom: Photographs of the transition zones where normal stem wood changed into buried stem wood and vice versa. The numbers indicate the year in which the first and last complete visible tree ring on the photograph was formed. The arrow indicates the point where the transition occurred. Growth proceeds from left to right. 

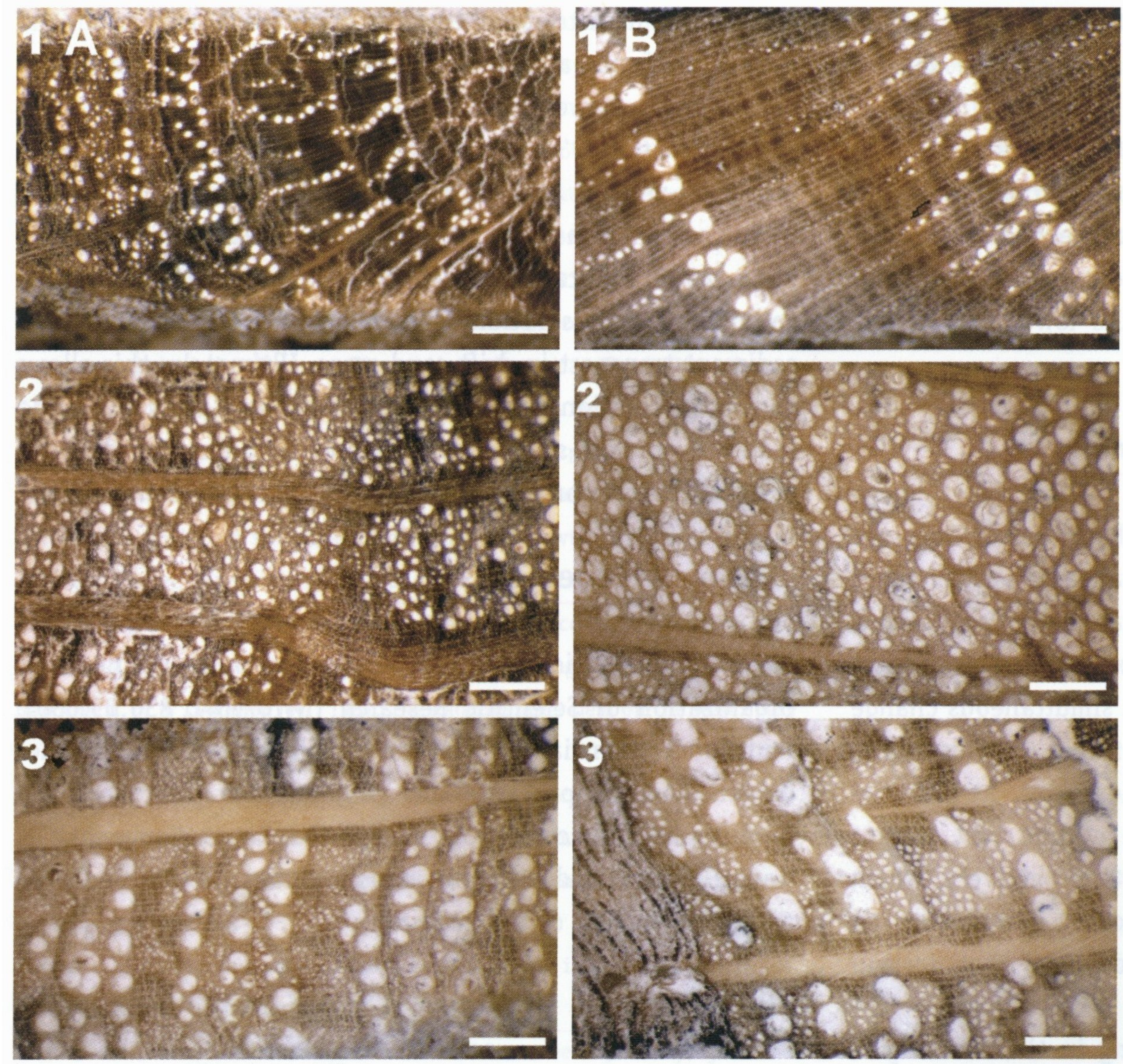

Fig. 7. Changes in wood anatomy of oak (Quercus robur) as a result of burial by sand and exposure after erosion.

A. Wood anatomy of the root of an oak from the Loonse en Drunense Duinen (LDD). The sample was taken from the lowest sample position as indicated in Fig. 3; 1 . Tree rings close to the pith with a clear root wood anatomy; 2. Long lasting growth depression (root wood) during the period in which the root was buried deeper after being covered by drift sand; 3. Distinct tree rings with a ring-porous anatomy are formed when the root became exposed after erosion.

B. Wood anatomy of an oak stem from the Deelensche Start (DS). The sample was taken from the location indicated in figure 4 (top); 1 . Tree rings around the pith with the distinct ring-porous anatomy of aerial stem wood; 2. Extremely narrow rings, resembling the anatomy of deep root wood, that were formed after the stem was covered by drift sand; 3. Distinctly ring-porous tree rings were formed again after the buried stem part was exposed again after erosion. photographs) the first transition is characterized by a sharp decrease in ring width together with a drastic decrease in the amount of latewood. Vessel size decreased considerably during a long-lasting growth depression (Fig. 7A2). The second transition in all samples showed again a strong increase in ring width, with the wood becoming clearly ring porous (Fig. 7A3). This second transition was dated to 1978,1948 and 1946 for the samples collected at $0.2,0.8$, and $1.2 \mathrm{~m}$ height respectively.

\section{Discussion}

\section{Tree morphology}

In both oak clusters (LDD and DS), the samples taken from below the thickened stem parts showed sudden changes in wood anatomy and ring width, while the samples above that point show no such changes and consisted of distinctly ringporous wood across the entire radius of the stems. The aberration from normal stem or root wood in the lower stem parts indicates that these parts had experienced a change in the local environment.

The narrow age range of the higher stem parts (above the line in Figs 3 and 4) suggests that these stems started growing around the same year. Together with the fact that very wide rings are formed during the first up to 10 years followed by a rapid decrease in tree-ring width (Figs 5 and 6) this is a clear indication of simultaneous re-growth after cutting. This growth pattern is consistent with the re-growth pattern of sprouts on stumps (Copini et al., unpublished results). Based on the maximum ages, we estimate that the trees have been cut around 1927 in LDD and 1919 in DS. The thickened parts of the stems indicated the level where the former generation of stems was cut. As it can be assumed that cutting took place near the soil surface (Boer, 1857), the thickened stem part thus represents the approximate level of a former soil surface in 1927 (LDD) and 1919 (DS), respectively.

\section{Wood-anatomical changes}

The anatomy of the first-formed (juvenile) wood in the lower parts of the trees indicates that at the lowest sampled location of the oak cluster in LDD (Fig. 3), the structure started as a root (Fig. 7A1). At all other sampled locations in both sites, stems started growing as aerial shoots. The subsequent change in wood anatomy and ring width is consistent with changes that have been observed in stems that become buried by sand (Wieler 1891; Heikkinen and Tikanen, 1987; Filion and Marin, 1988; Marin and Filion, 1992; Strunk, 1997), or roots that are buried deeper in the soil. These changes in wood anatomy mainly comprise a decrease in the amount of latewood and distinct changes in early-wood vessel size (Fig. 7), reflecting a drastic change in cambial activity. It is not clear yet as to what environmental variables bring about these changes, but these may include reduced temperature and/or oxygen levels 
or the increased pressure by the covering substrate (Fayle, 1968; Marin \& Filion, 1992; Cournoyer \& Filion, 1994; Gärtner et al., 2001; Gärtner, 2003).

Marin \& Filion (1992) showed that when stems of Picea glauca were re-exposed after burial, they started producing rings that were approximately of the same width as rings produced before burial. This is consistent with the second transition found in our samples from the lower part of the trees at LDD and DS.

\section{Potential for dating drift-sand dynamics}

The changes in wood anatomy induced by burial or exposure of stems or roots occur most likely instantaneously. Changes in ring width may show a delay of several years (Cournoyer \& Filion, 1994). Our data indicate that exposure of previously buried stems and roots is expressed by a simultaneous change in wood anatomy and ring width (Figs 5 and 6). This allows exact dating of erosion events and erosion rates. At LDD, the locations at 1.2 and $0.8 \mathrm{~m}$ above the current soil surface (Fig. 5) were exposed in 1946 and 1948 respectively, which yields an erosion rate of $0.2 \mathrm{~m} \cdot \mathrm{y}^{-1}$. The lowest sample location at $0.2 \mathrm{~m}$ became exposed in 1978, indicating that erosion rates decreased to $0.02 \mathrm{~m} \cdot \mathrm{y}^{-1}$.

A period of sand deposition, resulting in the covering of stems or deeper burial of roots did result in a simultaneous change in wood anatomy and ring width in LDD. However, in DS prior to the first transition starting at 1823, radial growth had already decreased a number of years before the anatomical change occurred in the wood (Fig. 6). This difference is probably induced by one or more sand deposition events prior to the covering of the stem at the sampled location in the structure. At this moment it remains unknown how changes in wood anatomy and ring width in the stem or root are related to the exact position of the new soil surface. Detailed observations and experimental research are needed to determine withintree variation in wood anatomy and radial growth along the vertical axis of the stem and at different heights above, and depths below, the exact level of sand deposition.

Although only a limited amount of samples was taken, this pilot study has demonstrated that the history of covering and exposure of stems and roots is recorded in the wood of oaks growing in drift-sand areas. Changes in wood anatomy can be dated using dendrochronological techniques, resulting in a great potential to study the dynamics in drift-sand areas. Using this dendrogeomorphological approach, dune formation and erosion can be reconstructed in areas where trees are present and may allow for the reconstruction of aeolian activity with annual precision. An additional advantage of this method is the fact that the 'signals' of past deposition and erosion events are conserved in the wood. The records of past deposition and erosion events therefore remain present in the tree, even when the sand dunes are fully eroded. Dendrogeomorphology can thus be used to reconstruct drift-sand dynamics when the actual landforms are no longer present. No other method is able to do so. However, we still have to resolve questions as to what extent the 'signal' of covering or exposure is present along the vertical axis of the tree.

In combination with optical dating of sediments (Wallinga et al., 2007) in locations without trees, it will become possible to build a high resolution data set about dynamics of aeolian sediment transport in drift-sand areas. Ultimately, this allows the reconstruction of the effects of changes in climate and land-use on drift-sand dynamics, providing baseline data for restoration and conservation potential of active drift sands.

\section{Acknowledgements}

The wood anatomical research was funded by the Netherlands Organization of Scientific Research (NW0/AWL 836.05.030). Additional financial support was provided by Stichting Het Gelders Landschap. Bart Boers (DS) and Lex Querelle (LDD) kindly allowed access to the sample locations. Comments by Hans Huisman and an anonymous reviewer greatly improved an earlier version of this manuscript.

\section{References}

Alestalo, J., 1971. Dendrochronological interpretation of geomorphic processes. Fennia 105: 1-140.

Bakker, T., Everts, H., Jungerius, P., Ketner, R., Kooijman, A. Van Turnhout,

C. \& Esselink, H., 2003. Preadvies stuifzanden. Expertisecentrum LNV (Ede/Wageningen): $114 \mathrm{pp}$.

Bal, D.P.F., Beije, H.M., Fellinger, M., Haveman, R., Van Opstal, A.J.F.M. \&

Van Zadelhoff, F.J., 2001. Handboek natuurdoeltypen. Expertisecentrum LNV (Wageningen): $832 \mathrm{pp}$.

Ballarini, M., Wallinga, J., Murray, A.S., Van Heteren, S., Oost, A.P., Bos, A.J. \& Van Eijk, C.W.E., 2003. Optical dating of young coastal dunes on a decadal time scale. Quaternary Science Reviews 22, 1011-1017.

Boer, R.W., 1857. Bijdragen tot de kennis der houtteelt. Tjeenk Willink (Zwolle): 577 pp.

Buis, J., 1985. Historia forestis. HES \& De Graaf Publishers (Utrecht): 1058 pp.

Bodoque, J.M., Diez-Herrero, A., Martín-Duque, J.F., Rubiales, J.M., Godfrey, A., Pedraza, J., Carrasco, R.M. \& Sanz, M.A., 2005. Sheet erosion rates determined by using dendrogeomorphological analysis of exposed tree roots: Two examples from Central Spain. Catena 64: 81-102.

Copini, P., Buiteveld, J., Den Ouden, J. \& Sass-Klaassen U.G.W., 2005. Clusters of Quercus robur and Q. petraea at the Veluwe (the Netherlands). CGN Report 1 (Wageningen): 46 pp.

Cournoyer, L.C. \& Filion, L., 1994. Variation in the anatomy of white spruce in response to dune activity. Arctic and Alpine Research 26: 412-417.

Fanta, J., 1982. Natuurlijke verjonging van het bos op droge zandgronden. Rapport nr. 301, Rijksinstituut voor het onderzoek in de bos- en landschapsbouw 'De Dorschkamp' (Wageningen): 236 pp. 
Fayle, D.C.F., 1968. Radial growth in tree roots: distribution, timing, anatomy. Technical Report No. 9, Faculty of Forestry, University of Toronto (Toronto): $183 \mathrm{pp}$.

Filion, L. \& Marin, P., 1988. Modifications morphologiques de l'Épinette blanche soumise á la sedimentation éolienne en milieu dunaire, Québec subartique. Canadian Journal of Botany 66: 1862-1869.

Gärtner, H., 2003. Holzanatomische Analyse diagnostischer Merkmale einer Freilegungsreaktion in Jahrringen von Koniferenwurzeln zur Rekonstruktion geomorphologischer Prozesse. Dissertationes Botanicae, Band 378: 118 pp.

Gärtner, H., 2007. Tree roots - Methodological review and new development in dating and quantifying erosive processes. Geomorphology 86: 243-251.

Gärtner, H., Schweingruber, F.H. \& Dikau, R., 2001. Determination of erosion rates by analyzing structural changes in the growth pattern of exposed roots. Dendrochronologia 19: 81-91.

Grissino-Mayer, H.D., 2001. Evaluating crossdating accuracy: A manual and tutorial for the computer program COFECHA. Tree-Ring Research 57: 205-221.

Heikkinen, O. \& Tikkanen, M., 1987. The kalajoki dune field on the west coast of Finland. Fennia 165: 241-267.

Hitz, 0., Gärtner, H. \& Monbaron, M., 2006. Reconstruction of erosion rates in Swiss mountain torrents. In: Heinrich, I., Gärtner, H., Monbaron, M. \& Schleser, G. (eds): TRACE - Tree Rings in Archaeology, Climatology and Ecology 4, 196-202.

Holmes, R.L., 1983. Computer-assisted quality control in tree-ring dating and measurement. Tree-Ring Bulletin 43: 69-78.

Koster, E.A., 1978. De stuifzanden van de Veluwe, een fysisch-geografische studie. Universiteit van Amsterdam (Amsterdam): 226 pp.

Koster, E.A., 2005. The physical geography of Western Europe. Oxford University Press (0xford): $438 \mathrm{pp}$.

Marin, P. \& Filion, L., 1992. Recent dynamics of subarctic dunes as determined by tree-ring analysis of white spruce, Hudson Bay, Québec. Quaternary Research 38: 316-330.

Maun, M.A., 1998. Adaptations of plants to burial in coastal sand dunes. Canadian Journal of Botany 76: 713-738.

Riksen, M., Ketner-Oostra, R., Van Turnhout, C., Nijssen, M., Goossens, D., Jungerius, P.D. \& Spaan, W., 2006. Will we lose the last active inland drift sands of Western Europe? The origin and development of the inland driftsand ecotype in the Netherlands. Landscape Ecology 21: 431-447.

Rinn, F., 1996. TSAP (Time Series Analysis and Presentation) Version 3.0, Reference manual (Heidelberg): $262 \mathrm{pp}$.

Sahling, I., Schmidt, K.-H. \& Gärtner, H., 2003. Dendrogeomorphological analysis of the enlargement of cracks at the Wellenkalk-scarp in the southern Thuringia Basin. In: Schleser, G., Winiger, M., Bräuning, A., Gärtner, H., Helle, G., Jansma, E., Neuwirth, B. \& Treydte, K. (eds): TRACE Tree Rings in Archaeology, Climatology and Ecology 1: 125-130.

Schweingruber, F.H., 2001. Dendroökologische Holzanatomie. Paul Haupt (Bern): $472 \mathrm{pp}$.

Stoutjesdijk, $P_{.}, 1959$. Heaths and inland dunes of the Veluwe. A study of some of the relations existing between soil, vegetation and microclimate. Wentia 2: 1-96.

Strunk, H., 1997. Dating of geomorphological processes using dendrogeomorphological methods. Catena 31: 137-151.
Tesch, P., Hesselink, E. \& Valckenier Suringar, J., 1926. De zandverstuivingen bij Kootwijk in woord en beeld. Tekst bij den platenatlas. Staatsboschbeheer (Utrecht): $70 \mathrm{pp}$.

Wieler, A., 1891. Über die Beziehung zwischen Wurzel- und Stammholz. Tharandter Forstliches Jahrbuch 41: 143-171.

Wallinga, J., Davids, F. \& Dijkmans, J.W.A., 2007. Luminescence dating of Netherlands' sediments. Netherlands Journal of Geosciences 86/3: 179-196. 